\title{
DEVELOPING TAX ADMINISTRATION IN THE CONTEXT OF THE PARTNERSHIP OF PARTICIPANTS OF TAX RELATIONS
}

Tatyana Aleksandrovna Efremova

National Research Ogarev Mordovia State University, Saransk, (Russia Federation). E-mail: tatyanaaefremova@yandex.ru ORCID: https://orcid.org/0000-0002-8476-3632

Recepción: 22/04/2020 Aceptación: 01/06/2020 Publicación: 24/08/2020

Citación sugerida:

Efremova, T.A. (2020). Developing tax administration in the context of the partnership of participants of tax relations. 3C Empresa. Investigación y pensamiento crítico, 9(3), 109-123. https://doi.org/10.17993/3cemp.2020.090343.109-123 


\section{ABSTRACT}

The aim of the study is to elaborate methodological and practical recommendations to develop tax administration when forming tax relations based on the partnership, trust and mutual responsibility of tax authorities and taxpayers. The author uses general and special methods of scientific knowledge (the abstract-logical method, methods of analysis and synthesis, comparison and generalization, etc.) as a methodological base, which makes it possible to justify the need to change the form of the cooperation between the state (represented by tax authorities) and taxpayers, to assess the satisfaction of physical and legal entities with the quality of service in tax offices, and to elaborate a set of recommendations aimed at harmonizing the interests of the participants of tax relations. Results indicate that the transition to a socio-technological model for developing the tax service of Russia implies a refusal to serve taxpayers according to the formula "Long. Difficult. Inconvenient" in favor of the formula "Quick. Easy. Convenient. Professional". At the same time, modern information technologies and tax administration management systems are becoming a tool that ensures the development of the relationship between tax authorities and citizens and businesses. Their application allows the formation of informational and methodological support for taxpayers, which stimulates the voluntary fulfillment of tax obligations, and improves the quality of services offered to them by tax authorities. It can be concluded that forming tax relations based on the partnership of their participants helps to achieve positive results in developing tax administration.

\section{KEYWORDS}

Tax Administration, Tax Relations, Partnership, Taxpayers, Tax authorities, Tax offices. 


\section{INTRODUCTION}

The stability and sufficiency of the receipt of financial resources in the state budget, and consequently its economic and social development, are largely determined by the quality and effectiveness of tax administration. In this case, the conditions to improve fiscal performance are both the reduction of the possibility of tax evasion and the stimulation of taxpayers to pay their taxes voluntarily. This makes it necessary to change the power-dominated form of the cooperation between the participants of tax relations into partnership, which is based on creating a system-based customer-oriented approach to arranging the work of tax authorities with physical and legal entities. At the same time, the main emphasis is on forming a comfortable tax environment for taxpayers that simplifies the fulfillment of their tax obligations.

Nowadays the solution to this problem in Russia is possible, thanks largely to the introduction of information technologies in the tax sphere, which allows the more active involvement of taxpayers in the cooperation with tax authorities while they fulfill their tax obligations and implement the exchange of information. Therefore, further improving information and telecommunication technologies and developing electronic services are a priority for tax authorities. This makes it possible to form such information and methodological support for taxpayers that will nullify many tax violations and ensure the growth of the voluntary payment of taxes to the budget system of the country.

\section{LITERATURE REVIEW}

The problem of developing tax administration is one of the key issues in modern economic science. However, in Russia, the nature and content of tax administration and its arrangement began to be studied only in the first decade of the 2000s after the use of this term in a number of regulatory documents of federal executive bodies. Russian economists such as Aristarkhova et al. (2016), Aronov and Kashin (2006), Goncharenko (2009), Krasnitsky (2011), Mayburov (2007), Melnikova (2005), Mironova and 
Hanafeyev (2005), Mishustin (2010), Ospanov et al. (1997) have devoted their works to the study of tax administration.

Certain issues concerning the improvement of relations between the state and taxpayers were reflected in writings of such foreign scientists as Clemenza et al. (2010), Hauptman et al. (2014), and also in works of Russian researchers, Gashenko (2009), Peronko (2000) and others.

At the same time, if in most developed Western countries (the USA, UK, Switzerland, the Netherlands, Denmark, etc.) tax administration has long been based on a partnership model using a customer-oriented approach, mutual trust and mutually beneficial "exchange" of the managed with the managed, then in Russia the need to change the current system of tax relations is only being realized.

The priority in the work of the tax service is to create a systematic, client-oriented approach to arranging the work with physical and legal entities. The specifics of its forming and arranging was reflected in works of Walsh (2012), Demin (2016), Orlova (2013), Ponomarev and Ponomareva (2012) and others.

Thereafter, the implementation of the ideology of creating the most comfortable tax administration procedures for bona fide taxpayers was developed in the Strategic Map of the Federal Tax Service of Russia for the period of 2017-2021 (Strategic map of the Federal Tax Service of Russia for the period of 2017-2021), identifying such priority areas as reducing the administrative burden on taxpayers, simplifying the execution of tax procedures, and developing an open dialogue with business and society.

\section{METHODS}

The principles of a systematic approach to the study of tax relations were used, first of all, as a methodological base of the study, which made it possible to identify essential characteristics of the phenomena and processes under study, to determine their development trends, and to identify causes of contradictions between them. In addition, general and special methods of scientific knowledge were used in the course of the work: the abstract-logical method, methods of analysis and synthesis, 
comparison and generalization, system and structural analysis, economic and mathematical methods. As a whole, these research methods ensured the reliability of the economic analysis and the validity of the conclusions made.

\section{RESULTS}

Currently, Russia is undergoing a large-scale tax reform aimed at developing tax administration, bringing it nearer to the best international practices. The main attention is paid to improving relations and developing ties between the state, represented by tax authorities, and citizens, and businesses.

This problem can be solved by forming new approaches to tax administration based on the use of modern information technologies and management systems. The transition to a structural and technological foundation to form a globally competitive tax administration system, and to develop activities of tax authorities, taking into account the increase of opportunities to apply basic principles in the field of social skills, have determined the possibility of forming relations between tax authorities and taxpayers based on mutual trust, partnership and customer-oriented services.

To that end, in 2011, the Federal Tax Service of Russia adopted the concept of working with taxpayers, which determined an action strategy for the near future (The concept of working with taxpayers). It proposes a transition from a technological model for developing the Federal Tax Service of Russia to a socio-technological model, from serving taxpayers according to the formula "Long. Difficult. Inconvenient" to the formula "Quick. Easy. Convenient. Professional".

The concept of the Federal Tax Service of Russia to work with taxpayers aims to increase the level of fulfilling tax obligations by taxpayers, and to improve the image of the Federal Tax Service of Russia by developing an understandable, convenient, and economically viable tax administration while providing state services and serving taxpayers. 
State tax services are services provided by tax authorities to carry out activities aimed at securing rights, freedom, and protection of interests of physical and legal entities, including providing registration, information, and interactive services using information technologies (Efremova \& Efremova, 2015; Aberbach \& Christensen, 2007; Besfamille \& Siritto, 2009; Mansor \& Tayib, 2013).

The implementation of state tax services serves to simplify procedures to execute tax obligations by taxpayers. That is, the tax authority should be transformed from a fiscal structure into a service that focuses on the taxpayer's interests.

The social orientation of developing the tax service is aimed at changing the architecture and technological platform of the department, taking into account a client-oriented refinement, which should provide a technological foundation that generates convenient services and opportunities for high-quality service to taxpayers.

To do this, non-contact forms of cooperation with taxpayers based on new information technologies are being developed. So, to get many services, taxpayers only need to use the tax service website, which hosts a variety of interactive services, thanks to which they can find out the address and opening hours of the local tax office, make an appointment, find any necessary information to calculate taxes and to pay them, check their counterparties, have a look at the Unified State Register of Legal Entities and the Unified State Register of Enterprises, and register as a legal entity or individual entrepreneur.

The quality of the work of tax authorities in their interface with taxpayers depends on how the services offered to the latter correspond to their needs and requests. It can be characterized using indicators such as the number of citizens and organizations getting information from the Unified State Register of Legal Entities and the Unified State Register of Industrial Enterprises with the help of internet technologies; the proportion of taxpayers having access through communication channels and Internet to personalized information on the status of budget settlements; the efficiency of considering incoming requests; and the share of taxpayers reporting by telecommunication channels. 
However, by no means all of these indicators have quantification. In addition, there is no generally accepted methodology to assess the quality of the services of tax authorities. In this regard, we can use the methodology proposed by Zhukova (2008), which is based on the taxpayer satisfaction index that shows how services offered by tax authorities comply with his/her requirements and wishes. However, we consider it necessary to exclude the absolute value of the taxpayer satisfaction index, and to use the ratio of the calculated index value to its maximum possible value.

Then, the formula for the quality index of services offered by tax authorities to taxpayers will look like this:

$$
Q_{t}=\frac{\sum_{i=1}^{n} F_{i} I_{i}}{\max \sum_{i=1}^{n} F_{i} I_{i}}
$$

\section{Where:}

$\mathrm{F}_{\mathrm{i}}$ is the level of fulfilling the $\mathrm{i}$-th taxpayer satisfaction criterion;

$\mathrm{I}_{\mathrm{i}}$ is the level of importance of the $\mathrm{i}$-th satisfaction criterion for the taxpayer; $n$ is the number of satisfaction criteria.

We have selected the following satisfaction criteria:

- The rate of serving taxpayers.

- The competence, courtesy, and correctness of tax inspectors.

- The convenience of the tax authorities' website.

- The ease and availability of internet services offered by tax authorities.

- The efficiency of considering incoming requests. 
We consider the optimal rating scale to be from 1 to 5 , both for the level of fulfilling the criterion and its importance for the taxpayer.

In assessing the quality of services offered by tax authorities to taxpayers, it is necessary to consider the opinion of several respondents. Thus, it is advisable to use a modified formula for the quality index of the work of tax authorities with taxpayers:

$$
=\frac{\sum_{i=1}^{5} R_{i} I_{i} \alpha+\sum_{i=1}^{5} C_{i} I_{i} \alpha+\sum_{i=1}^{5} \operatorname{Cint}_{i} I_{i} \alpha+\sum_{i=1}^{5} A i n t_{i} B_{i} \alpha+\sum_{i=1}^{5} E_{i} I_{i} \alpha}{125 \beta}
$$

Where: $\mathrm{R}_{\mathrm{i}}$ is the level of fulfilling the rate of serving taxpayers;

$\mathrm{C}_{\mathrm{i}}$ is the level of fulfilling the competence, courtesy and correctness of tax inspectors;

Cint $_{\mathrm{i}}$ is the level of fulfilling the convenience of the tax authorities' website;

Aint $_{i}$ is the level of fulfilling the availability of internet services offered by tax authorities;

$\mathrm{E}_{\mathrm{i}}$ is the level of fulfilling the efficiency of considering requests from taxpayers received by tax authorities;

$a$ is the number of people who preferred the i-th level of satisfaction with the criterion under consideration at the $\mathrm{i}$-th level of its importance;

$\beta$ is the number of people participating in the survey; and 125 is the maximum value of fulfilling all considered criteria of the taxpayer satisfaction with the maximum level of importance.

Using the proposed methodology, we conducted a survey of taxpayers, in which 87 respondents took part. Moreover, their opinion on the problem under study was divided as follows (Table 1). 
Table 1. The matrix of distributing respondents' answers according to the level of fulfilling criteria of the satisfaction with the quality of the work of tax authorities in accordance with their importance, people

\begin{tabular}{|c|c|c|c|c|c|c|c|}
\hline \multirow[t]{2}{*}{ Criteria } & \multirow{2}{*}{\multicolumn{2}{|c|}{ level of fulfilling }} & $\begin{array}{c}\text { very } \\
\text { important }\end{array}$ & important & $\begin{array}{c}\text { rather } \\
\text { important } \\
\text { than } \\
\text { unimportant }\end{array}$ & $\begin{array}{c}\text { of little } \\
\text { importance }\end{array}$ & unimportant \\
\hline & & & 5 & 4 & 3 & 2 & 1 \\
\hline \multirow{5}{*}{ 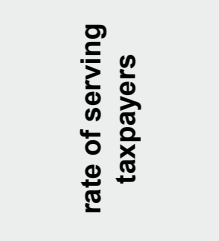 } & very high & 5 & 13 & 7 & & & \\
\hline & high & 4 & 21 & 11 & & & \\
\hline & acceptable & 3 & 10 & 7 & & & \\
\hline & low & 2 & 8 & 5 & 1 & & \\
\hline & very low & 1 & 3 & 1 & & & \\
\hline \multirow{5}{*}{ 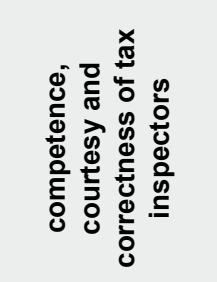 } & very high & 5 & 9 & 15 & & & \\
\hline & high & 4 & 13 & 19 & 1 & & \\
\hline & acceptable & 3 & 7 & 11 & 1 & & \\
\hline & low & 2 & 4 & 5 & 1 & & \\
\hline & very low & 1 & 1 & & & & \\
\hline \multirow{5}{*}{ 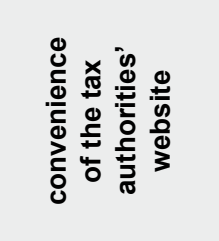 } & very high & 5 & 5 & 10 & & & \\
\hline & high & 4 & 10 & 19 & 9 & & \\
\hline & acceptable & 3 & 7 & 14 & 10 & & \\
\hline & low & 2 & & 1 & 1 & 1 & \\
\hline & very low & 1 & & & & & \\
\hline \multirow{5}{*}{ 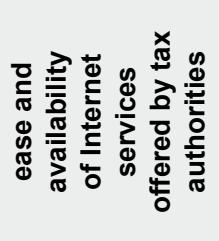 } & very high & 5 & 6 & 15 & & & \\
\hline & high & 4 & 7 & 25 & 11 & 1 & \\
\hline & acceptable & 3 & & 5 & 13 & 1 & \\
\hline & low & 2 & 1 & & 1 & 1 & \\
\hline & very low & 1 & & & & & \\
\hline
\end{tabular}




\begin{tabular}{|c|c|c|c|c|c|c|c|}
\hline \multirow[t]{2}{*}{ Criteria } & \multirow{2}{*}{\multicolumn{2}{|c|}{ level of fulfilling }} & $\begin{array}{c}\text { very } \\
\text { important }\end{array}$ & important & $\begin{array}{c}\text { rather } \\
\text { important } \\
\text { than } \\
\text { unimportant }\end{array}$ & $\begin{array}{c}\text { of little } \\
\text { importance }\end{array}$ & unimportant \\
\hline & & & 5 & 4 & 3 & 2 & 1 \\
\hline \multirow{5}{*}{ 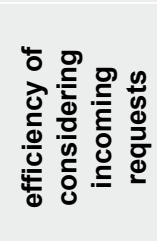 } & very high & 5 & 9 & 2 & & & \\
\hline & high & 4 & 20 & 4 & & & \\
\hline & acceptable & 3 & 34 & 3 & & & \\
\hline & low & 2 & 9 & 2 & & & \\
\hline & very low & 1 & 4 & & & & \\
\hline
\end{tabular}

Using the survey results, we calculated the resulting index, amounted to $64.2 \%$, which indicated an acceptable level of fulfilling all the criteria, and at the same time the need for further development of the cooperation between tax authorities and taxpayers in order to better satisfy interests of the latter (Efremova \& Efremova, 2016; Efremova, 2017).

\section{DISCUSSION}

Forming relations between tax authorities and taxpayers, based on partnership and customer-oriented service, contributes to the growth of mutual trust and respect. In this regard, we have defined a set of measures aimed at bringing together interests of participants of tax relations:

Firstly, developing customer-oriented communications, improving tax culture and the motivation of taxpayers. So, when developing information materials, it is necessary to consider needs of individual target groups of taxpayers, as well as to use different channels for their promotion. It is necessary to hold activities aimed at improving tax and legal literacy, tax culture and the motivation of taxpayers through informing, assisting in registration actions, developing tax competencies taking into account specifics, needs and capabilities of taxpayers. In order for information materials and the form of their submission 
to be available and useful for taxpayers of different educational levels, specialists in the field of marketing and communication theory should be involved in working on them together with tax professionals.

Secondly, developing the business culture of the Federal Tax Service of Russia, which ensures improving the quality of serving taxpayers by increasing communicative and professional competencies of tax inspectors.

Thirdly, developing an external environment that helps taxpayers fulfill their tax obligations. Structures capable of assisting taxpayers in fulfilling their tax obligations, including tax consultants, auditors, professional associations, chambers of commerce, business unions, etc., should be involved in a single value system. The purpose of this trend is to create a stable tax environment to support the mass taxpayer in fulfilling his/her tax obligations, to improve the cooperation and integration of efforts of tax authorities and external structures to serve taxpayers, as well as to create a positive attitude of the population and organizations to the tax system and activities of the Federal Tax Service of Russia.

Fourthly, ensuring the extraterritoriality of the taxpayer in relation to tax authorities. Extraterritoriality is the freedom of the taxpayer to gain access to information and services, regardless of a registration and location. The trend involves a set of structural and functional measures to break the current taxpayer connection with a registration and location, as well as to provide remote services to taxpayers by specialized structures that perform functions of mass data processing, as well as telephone and internet informing.

Fifthly, creating a comfortable taxpayer service area, including: increasing working time of tax offices; introducing unified time standards (waiting time for a response to a phone call, performing certain technological procedures); installing payment terminals in tax offices for the convenience of taxpayers to pay stamp duties; equipping customer floors and other areas to serve customers with computers specially designated for taxpayers connected to public tax and regulatory information; equipping customer 
floors and other areas to serve customers with related services (pharmacy, drink and snack machines, photocopying, etc.).

\section{CONCLUSION}

Thus, developing tax administration largely depends on the cooperation between participants of tax relations. At the same time, building a system customer-oriented approach of tax authorities to arranging the work with physical and legal entities based on the combination of principles of partnership and mutual responsibility is one of conditions for stable functioning of the tax system and state economy.

Tax administration, based on the partnership of participants of tax relations, serves to help achieve the following positive results in its development:

- Improving fiscal performance;

- Reducing administrative barriers;

- Improving the transparency of the Federal Tax Service of Russia, ensuring the availability of state services provided by the department;

- Raising the awareness of taxpayers about activities of the Federal Tax Service of Russia and services offered, improving the motivation of taxpayers to fulfill their tax obligations, enhancing people's trust in state authorities and improving the quality of state administrative bodies' activities;

- Developing the business culture of the Federal Tax Service of Russia as a client-oriented organization, motivating employees of the Federal Tax Service of Russia to provide the high quality of state services and taxpayer serving;

- Involving external organizations in providing support to taxpayers to fulfill their tax obligations;

- Ensuring extraterritoriality and standardization of tax procedures, enlarging structures offering mass services; 
- Qualitative extending of distance cooperation for broad layers of taxpayers while improving the quality of face-to-face cooperation;

- Building the image of the Federal Tax Service of Russia in the eyes of taxpayers as a service that ensures an absolute tax collection while respecting interests and needs of taxpayers.

\section{REFERENCES}

Aberbach, J. D., \& Christensen, T. (2007). The challenges of modernizing tax administration: Putting customers first in coercive public organizations. Public Policy and Administration, 22(2), 155182. https://doi.org/10.1177/0952076707071501

Aristarkhova, M. K., Alchinova, A. R., Varavina, K. S., \& Melnikova, K. S. (2016). Tax administration as a modern stage of the tax reform. Collection "Modern tax system: state, problems and development prospects" FSBEEHH Ufa State Aviation Technical University, 31-33.

Aronov, A. V., \& Kashin, V. A. (2006). Tax Policy and Tax Administration: A Study Guide. - M.: Economist,. $-188 \mathrm{p}$.

Besfamille, M., \& Siritto, G. P. (2009). Modernization of tax administrations and optimal fiscal policies. Fournal of Public Economic Theory, 11(6), 897-926. https://doi.org/10.1111/j.14679779.2009.01437.x

Glemenza, G., Gotera, A., \& Araujo, R. (2010). Quality of services rendered by the muncipal autonomous tax administration service [Calidad de los Servicios prestados por el Servicio Autónomo Municipal de Administración Tributaria]. Revista Venezolana de Gerencia, 15(49), 103124. 
Demin, A. V. (2016). Improving tax culture is the most important component of the transition to the "partner" model of tax administration. Materials of the VIII International research and practice conference "Actual trends of scientific researches: from theory to practice". Cheboksary: CNS "Interactio plus", 2(8), 271275.

Gashenko, I. V. (2009). Methodological foundations of tax regulation. Tax policy and practice, 9.

Goncharenko, L. I. (2009). Tax Administration: A Study Guide. - M.: KNORUS, - 342 p.

Hauptman, L., Horvat, M., \& Korez-Vide, R. (2014). Improving tax administration's services as a factor of tax compilance: The case of tax audit. Lex Localis, 12(3), 481-501.

Krasnitsky, V. A. (2011). Theory and Practice of Modern Tax Administration. ANEE HPE Odintsovo Humanitarian Institute, - 196 p.

Mansor, M., \& Tayib, M. (2013). Integrated and open systems model: An Innovative approach to tax administration performance management. Innovation fournal, 18(3). http://citeseerx.ist.psu.edu/ viewdoc/download?doi=10.1.1.641.6141\&rep=rep $1 \&$ type $=$ pdf

Mayburov, I. A. (2007). Tax policy. Theory and practice. - M.: YuNITI-DANA, - 512 p.

Melnikova, N. P. (2005). Actual problems of the theory and practice of tax administration in the Russian Federation. Review of speeches at a round table meeting. Your tax lawyer, 6, 41-45.

Mironova, O. A., \& Hanafeyev, F. F. (2005). Tax administration. M.: Omega-L. - 222 p.

Mishustin, M. V. (2010). Improving the quality and effectiveness of tax administration. Russian Tax agent, $13-14$.

Orlova, E. Yu. (2013). Electronic document flow as a tool to improve the efficiency of tax administration procedures. Modern trends in economics and management: a new look, 23, 177-183. 
Ospanov, M. T. (1997). Tax Reform and Harmonization of Tax Relations. SPb: UEF, - 488 p.

Peronko, I. A. (2000). Methods and forms of tax administration. Tax Bulletin, 11, 9-12.

Ponomarev, A. I., \& Ponomareva, A. M. (2012). Modernization of tax administration in modern Russia. Taxes and taxation, 3, 30-37.

Strategic map of the Federal Tax Service of Russia for the period of 2017-2021. https://www.nalog.ru/ rn77/about_fts/fts/ftsmission/

The concept of working with taxpayers. nalog:ru/html/docs/concept_resume.docx

Walsh, K. (2012). Understanding taxpayer behaviour - new opportunities for tax administration. Economic and Social Review, 43(3), 451-475.

Efremova, T. A. (2017). Improving the work of tax authorities with taxpayers in the context of a service-oriented tax administration model. Taxes, 3, 36-40.

Efremova, T. A., \& Efremova, L. I. (2015). Developing the system of offering state services by tax authorities to physical and legal entities based on information technologies. Economics. Taxes. Lawe, $1,139-143$.

Efremova, T. A., \& Efremova, L. I. (2016). The quality of information exchange between tax authorities and taxpayers: an integrated assessment. Taxes, 6, 15-21.

Zhukova, L. E. (2008). Evaluating the quality of services offered by tax authorities, or how to calculate the taxpayer satisfaction index. Tax policy and practice, $8,70-74$. 